Research Report No. 37/2010

\title{
The Conundrum of Order: The Concept of Governance from an Interdisciplinary Perspective
}

Peer Zumbansen

Osgoode Hall Law School of York University, PZumbansen@osgoode.yorku.ca

Follow this and additional works at: http:// digitalcommons.osgoode.yorku.ca/clpe

\section{Recommended Citation}

Zumbansen, Peer, "The Conundrum of Order: The Concept of Governance from an Interdisciplinary Perspective" (2010).

Comparative Research in Law \& Political Economy. Research Paper No. 37/2010.

http://digitalcommons.osgoode.yorku.ca/clpe/104 


\section{OSGOODE}

OSCOODE HALL LAW SCHOOL

YOR K UNIVERSITY

\section{OSGOODE HALL LAW SCHOOL}

Comparative Research in Law \& Political Economy

RESEARCH PAPER SERIES

Research Paper No. 37/2010

\section{The Conundrum of Order: The Concept of Governance from an Interdisciplinary Perspective}

Peer Zumbansen

\section{Editors:}

Peer Zumbansen (Osgoode Hall Law School, Toronto, Director, Comparative Research in Law and Political Economy)

John W. Cioffi (University of California at Riverside)

Lisa Philipps (Osgoode Hall Law School, Associate Dean Research)

Nassim Nasser (Osgoode Hall Law School, Toronto,

Production Editor)

Comparative Research in Law \& Political Economy 
CLPE Research Paper 37/2010

Vol. 06 No. 8 (2010)

Peer Zumbansen

\title{
The Conundrum of Order: The Concept of Governance from an Interdisciplinary Perspective
}

\begin{abstract}
The term governance has made an impressive career in a number of disciplines concerned with regulation, order and law. This chapter draws on insights from legal studies, sociology, political science, anthropology, history and geography to paint a multifaceted picture of existing, competing and complementing approaches to the concept of governance. For reasons of space, the chapter can but point to the different variations on a theme, as governance occupies an ambivalent place in past and present discourses on political (or, legal or economic) order and society. It is argued that beyond pointing to crucial phases of methodological and theoretical transformation within different disciplines such as the often perceived transition 'from government to governance', governance is itself a deeply interdisciplinary concept.
\end{abstract}

Key words: governance, regulation, economic governance, regulatory governance. Jel Classification: K 33

Forthcoming in: David Levi-Faur (ed.), The Oxford Handbook of Governance (Oxford University Press, 2011)

\section{Peer Zumbansen}

Professor of Law

Canada Research Chair in Transnational Economic Governance and Legal Theory, Osgoode Hall Law School, York University, Toronto.

Director, Critical Research Laboratory in Law \& Society.

Email: Pzumbansen@osgoode.yorku.ca 


\title{
The Conundrum of Order: The Concept of Governance from an Interdisciplinary Perspective
}

\author{
Peer Zumbansen*
}

\section{INTRODUCTION}

Governance, often conceived as an opposite to 'government', occupies an ambivalent place in past and present discourses on political (or, legal or economic) order and society. Its ambiguity is largely owed to the relative openness of the concept on the one hand and the resulting challenges of neatly demarcating it from other concepts on the other. Governance appears in such different uses, contexts and functions, that this alone should render the concept anything but useful as a key notion in contemporary and ongoing social research. This chapter seeks to respond to this challenge by addressing the concept's non-finite substantial content and formal/institutional fluidity through a series of investigations from the standpoint of different disciplinary frameworks. Connecting these investigations is an overarching element inherent to each discipline's respective treatment and use of the concept, namely that governance depicts more of an empty, still-to-be-defined space for conceptual clarification than a clearly identifiable political construct, institutional framework or historical period. As a consequence, all engagement with the concept - as reflected in each of the mentioned disciplines - is contentious in nature. But, while governance-related discourses in disciplines such as political philosophy and, clearly, in law, immediately evoke tensions of polarity, conflict and dispute, in other disciplines - surely, economics - the concept governance captures above all the experimental and tentative character of the concept. It is between these conflictual and experimental dimensions of the concept that the following chapter will attempt to carve out a number of core elements constituting the concept from an interdisciplinary perspective. At the end of this process, governance will emerge as an in itself interdisciplinary concept.

\section{VARIATIONS ON A THEME}

The emergence of 'globalisation studies' in the last two decades of the twentieth century drew attention to the translation challenges facing social studies that had for the longest time been developing their analytical and conceptual toolkit in the context of a particular, historically evolved political order. Despite ubiquitous historical evidence of pre-state political order and non-state based legal regulation, the mindset of the majority of social sciences - with the

\footnotetext{
* Professor of Law. Canada Research Chair in Transnational Economic Governance and Legal Theory, Osgoode Hall Law School, York University, Toronto. Director, Critical Research Laboratory in Law \& Society. This chapter was written during my fellowship at the Hanse Institute of Advanced Study, Delmenhorst (Germany), Summer 2010. I am grateful for comments from Alexandra Kemmerer, Maria Panezi, Alain Pottage and the participants of the Summer School on 'Kulturtechniken des Rechts', at the Bauhaus University in Weimar, 23-27 August 2010. This chapter is dedicated to the memory of Cornelia Vismann. Pzumbansen@osgoode.yorku.ca / www.criticalresearchlab.org
} 
exception of, say, anthropology ${ }^{1}$ - seemed to be shaped by the Westphalian Order since 1648. This context is, at least in part, responsible, that many social sciences today are drawn to contrast the term governance to the less fluid, historically evidential construct of (state-based) government. The tentative conceptualisation of non-state based political and legal order was clearly one of the significant traits of the fast proliferating study of globalisation. ${ }^{2}$ It is against this background that social science research before and surely since the millennium turn is marked by an overwhelming amount of thought and inquiry devoted to the prospects of 'global governance'. In the context of scrutinizing the legitimacy base of existing international institutions such as the World Bank, the World Trade Organization or the International Monetary Fund, references to governance overwhelmingly serve the purpose of highlighting the troubling, unresolved foundations of the above institutions from the viewpoint of political philosophy ${ }^{3}$, democratic theory ${ }^{4}$ and, certainly, law. ${ }^{5}$ Not only is the term employed to highlight the stark discrepancies between established traditions of the 'Rule of Law' or comparable political institutional frameworks on nation-state level and the fragmentary elements of world government on the global scale. Moreover, references to global governance can aptly capture the high legitimacy costs connected to the evolutionary design of political control in the discourses focusing on the 'post-national constellation' (Habermas) as on the transnational structure of the world. ${ }^{6}$ In particular the dramatic expansion of global financial markets, in the wake of which governments began to feverishly engage in a competition to outdo each other in the lowering of barriers for capital (and corporate) mobility, labour and services, has been associated with the overarching political goal of aspiring to create conditions of 'good (global) governance'. The frustratingly failing efforts to establish comparable frameworks of political accountability and representation to 'constitutionalise' the seemingly insatiable growth of global markets are a powerful illustration of the powerlessness of state-based theories of

\footnotetext{
${ }^{1}$ Malinowski, Geertz (Riles)

2 Drahos/Braithwaite, 2001; Saskia Sassen, The State and Globalization, in: Rodney Bruce Hall \& Thomas J. Biersteker eds., The Emergence of Private Authority in Global Governance (Cambridge University Press, 2002, $3^{\text {rd }}$ print.), 91-112; Claire Cutler, 2003

3 John Gerard Ruggie, International Regimes, Transactions, and Change: Embedded Liberalism in the Postwar Economic Order, 36 (2) International Organization (1982), 379-415.

4 Jürgen Habermas, A Political Constitution for the Pluralist World Society?, in: ibid., Between Naturalism and Religion. Philosophical Essays (polity, 2008 [German: 2005]), 312-352; David Held, Democratic Accountability and Political Effectiveness from a Cosmopolitan Perspective, 39 (2) Government and Opposition 364-391 (2004).

${ }^{5}$ Benedict Kingsbury, Nico Krisch \& Richard B. Stewart, The Emergence of Global Administrative Law, 68 Law \& Contemporary Problems (2005), 15-61; Carol Harlow, Global Administrative Law: The Quest for Principles and Values, 17 European Journal of International Law (2006), 187-214.

${ }^{6}$ Jessup, 1956; Zumbansen, 2006; Scott, 2009
} 
government to domesticate actors and processes of globalisation. ${ }^{7}$ Some time before, similar insights were gained in the context of the European Union's ongoing struggle to bridge economic freedoms with the development of political cohesion. ${ }^{8}$ Research strands such as 'regulatory governance', 'regulatory capitalism' ${ }^{10}$ as well as critical law \& development analyses ${ }^{11}$ seek to build on such insights by further scrutinising the treacherousness of claims of 'good governance' on a global scale. ${ }^{12}$

To be sure, however, governance had risen to a key notion in contemporary social studies - as well as economics !- well before the interest in the study of 'globalisation' as such. The transformation of the Western welfare state in the latter half of the twentieth century has often been connotated with a progress from government to governance, marked by a significant transformation of the role of the state in both the establishment and provision of social, formerly 'public' services. A closer look at the alleged 'retreat of the state' (Susan Strange) over the past decades has begun to open important vistas on the impressive role that the state has been continuing to play in the regulation and administration 'after the welfare state'. ${ }^{13}$ Importantly complementing accounts in legal theory and sociology of law of the emergence of 'responsive' and 'reflexive' modes of law in a dramatically changed regulatory context marked by privatization and so-called deregulation ${ }^{14}$, scrutiny of the regulatory foundations of pre-2007/2008 crisis financial markets has revealed significant regulatory presence of the state only too often characterised as 'self-regulated' and ruled by the rules of the market. The emerging insights into the complex forms of regulation, co-regulation, shared by public and private actors and expert-rule that have grown over the course of the last twenty or thirty years of the twentieth and in the first decade of the twenty-first century put the neoliberal assertion of allegedly efficient, 'unfettered' markets and the dysfunctional role of state intervention into sharp relief. ${ }^{15}$

\footnotetext{
${ }^{7}$ David Kennedy, The Mystery of Global Governance, in: Jeffrey L. Dunoff \& Joel Trachtman eds., Ruling the World (Cambridge University Press, 2009), 37-68

${ }^{8}$ Joerges(ed.), Symposium on Comission White Paper „European Governance“, Jean Monnet WP

${ }^{9}$ E.g. www.privateregulation.eu; Scott, 2004.

${ }^{10}$ Levi-Faur, 2005; Braithwaite, 2008.

${ }^{11}$ Rittich, 2005; Santos, 2006

${ }^{12}$ Weiss, 2000

${ }^{13}$ Harlow, 2009 HIDDEN PAW; Zumbansen, Law after the Welfare State

${ }^{14}$ Teubner, 1983

${ }^{15}$ Deakin, in Zumbansen/Willams 2010; Campbell, The End of Posnerian Law \& Economics
} 
More radically, still, political ecologists have been calling into question the merits of tying an analysis of governance and problem solving to concepts of democratic governance or to the framework of the state. Dissatisfied by what they describe as a 'absurdly unrealistic epistomology', such scholars argue for turn away from a focus on 'people' and instead for an orientation towards issues, or 'things' as the target of governance theory. Following from this critique is the rejection of 'facts' as matters-of-facts, the regulation of which could be portrayed as the result of different and competing viewpoints and interests. Instead, scholars such as Bruno Latour have been pulling away the carpet from underneath the numerous self-assured assertions of what should be done about a particular set of facts ${ }^{16}$ - which has tremendous consequences for the way we can think about the role of law in governance. Law, it turns out from this perspective, will have to be measured by its capacity to thematise the various, constituting expectations that constitute 'facts' and make up a governance problem. ${ }^{17}$

With law, sociology and political science seemingly enamoured with the rapid growth of complex regulatory instruments 'between state and market' since the 1970s and 1980s, significant theoretical and eventually extremely influential work around the concept of governance was done by economists. Inspired by the irrefutable call-to-arms for a historically minded analysis of economic development ${ }^{18}$, neo institutional economics [NIE] evolved as a field increasingly interested in the nature of institutions constituting modern societies. Building on the idea and theory of 'path dependency ${ }^{19}$, NIE over time developed immensely fine-tuned analytical apparatus to study the dynamics between 'formal' and 'informal' institutions. While references to the former served as a stand-in for existing political frameworks including the state and law, the latter sought to capture the immensely rich reservoir of societal rules, customs, routines and 'social norms'. ${ }^{20}$ The rise of NIE into a fully-fledged social theory is likely to have occurred in the context of state transformation and globalisation as depicted above. This is further accentuated by the fact that its so far most influential impulses to other fields of social study - above all law and political science - have been in the context of theoretical and practical inquiries into more 'efficient' modes of social regulation in a dramatically altered landscape. The place of NIE within a larger, altogether highly influential expansion of 'law \& economics' into other social studies is an ambivalent one, and only in coming years will it become more clear how a legacy of NIE can look like in contrast to the dramatic revelations of

\footnotetext{
${ }^{16}$ Latour, 1993; Latour, 2005, 19, 21

${ }^{17}$ Vismann, 2000, 286; Pottage, 1998, 342

${ }^{18}$ North

${ }^{19}$ David 1985, 2010

${ }^{20}$ Williamson 2000
} 
false assumptions underlying pre-crisis economics. The awarding of the 2009 Nobel Prize to two outstanding NIE scholars - the economist Oliver Williamson and the political scientist Eleanor Ostrom - can be thus be seen as an important invitation to look beyond the black/white divide of formal and informal institutions and instead to further investigate the nature of and the dynamics between the respective types of institutions. It is here, where the study of 'economic governance', made famously since the 1990 s by scholars such as North and Williamson, stands to offer as much as to learn in a dialogue with (economic) sociologists and legal scholars. While the former have been reopening the debate around Polanyian concepts of disembedded markets ${ }^{21}$, the latter are called upon to complement NIE's depictions of formal/informal institutions with longstanding legal theoretical and legal sociological work into non-legal regulation and 'legal pluralism'. ${ }^{22}$

Insights are standing to be gained as well from an intensified appreciation of findings in disciplines such as history, anthropology and geography on the uses of the concept governance. For anyone interested in the development of said 'globalisation studies' the field of history has experienced a significant surge in recent years as a consequence of predominantly younger members of the discipline to challenge the state-based frameworks of political history in particular. By positing the need to pay closer attention to both the 'crossed' and the 'transnational' dimensions of historical evolution, these scholars have been calling for a reorientation or at least an opening of historical research for a perspective, that seeks to take into view the parallels and complementary processes occurring at particular times, in various states. Representatives of the field of 'histoire croisée ${ }^{23}$ and 'transnational history' ${ }^{24}$ in this respect started to enrich and complement 'national' histories with a still maturing but already highly dynamic perspective on the global dimension of historical development.

The contribution of anthropological research to governance studies as well has been significant. Harkening back to ground-breaking work on regulatory patterns in indigenous societies by scholars such as Mead, Malinowski or Geertz, present-day anthropologists have taken their discipline into the contested spheres of local rights generation ${ }^{25}$ as well as of transnational commercial activity. ${ }^{26}$ At the same time, anthropologists have turned to the intricate functional qualities of social 'materialities', 'facts' and 'media'. ${ }^{27}$ In search of the code and the driving

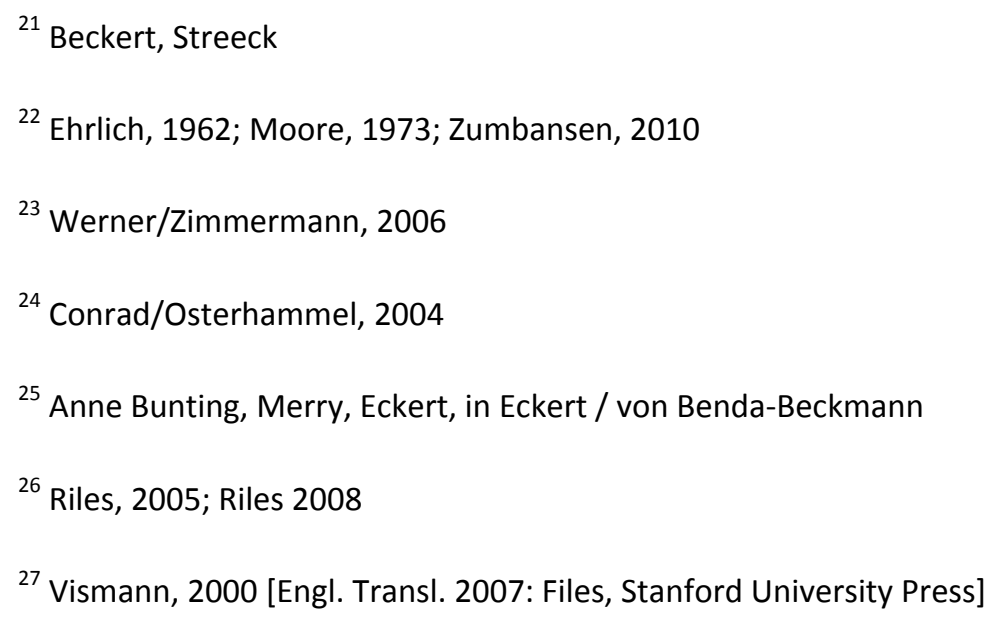


forces of societal activity, anthropology scholars and field workers have thus been making a meaningful contribution a better understanding of the form and nature of governance existing for example in the context of local human rights adversary activity but also within the fine arteries of real and intellectual property as well as cross-border contract drafting and dispute resolution. Human rights law meets legal pluralism ${ }^{28}$, commercial law meets sociology and anthropology ${ }^{29}$, legal theory meets literary criticism. ${ }^{30}$

Concluding this very cursory glance at different disciplinary engagements with the term governance, the field of geography - being itself at the intersection of various fields - occupies a crucial place. Critical economic and social geographers long pointed to the complex undercurrents of existing mappings of territories and landscapes, highlighting the laden assumptions and associations accompanying such respective geographical demarcations. Two sites of engagement are of particular importance in this regard. One is concerned with the notion of space in a globalising world. Geographers, more often than not functioning as simultaneous sociologists and social theorists, have been painting richly structured pictures of 'global spaces' that they see as constituted by sets of human or organisational activity ${ }^{31}$, particular constellations of, for example, power or violence. ${ }^{32}$ The prevalence of space over place in these studies is owed to the belief that the former alone can adequately capture the non-territorial and at the same time epistemological dimension of an area that is determined by a particular set of people, activities or ideas. ${ }^{33} \mathrm{~A}$ key focus of attention in this regard has been the city. Urban studies scholars, themselves made up from - inter alia - geographers, sociologists, anthropologists, legal scholars and cultural theorists ${ }^{34}$ have relentlessly been pushing the borders of their discipline to make sense of an altogether unruly entity. The city, as part of an often hierarchically structured political and administrative framework, has also been the focus of social critique ${ }^{35}$, political sociology ${ }^{36}$ and democratic theory ${ }^{37}$ as well as of a critical

\footnotetext{
${ }^{28}$ Wilson, 2006

${ }^{29}$ Dezalay/Garth, 1996; Garth, 2006.

${ }^{30}$ Chakrabarty, 2007; FANON

${ }^{31}$ See e.g. the contributions to Karin Knorr-Cetina and Alex Preda (eds), The Sociology of Financial Markets (Oxford University Press, 2005)

${ }^{32}$ Foucault/Miskowiec, 1986; Harvey, 2005

${ }^{33}$ See also Sassen, 2006

${ }^{34}$ Sassen, 2005

${ }^{35}$ Benjamin, Arcade Project
} 
strand in border-crossing legal, sociological and geographic theory. ${ }^{38}$ On another level, economic geography has been mapping and investigating the connections between 'spatial resource allocation' and economic development ${ }^{39}$, hereby complementing parallel endeavours undertaken by political economists and sociologists carving out the particular constellations between institutional structure and economic development. ${ }^{40}$

\section{BLINDED BY LIGHT? LEARNING FROM INTERDISCIPLINARITY}

From this interdisciplinary vanguard, the term governance illustrates the contested grounds of engaging with competing models and theoretisations of order. More generally, governance points to the tension between state and non-state based conceptualisations of political and social order. This observation alone does not render the concept any tighter, but it allows to fruitfully trace and exploit the term's openness and its apparent availability not only in different disciplinary discourses, but also within two distinct frameworks of political, legal and sociological theorizing - 'national' and 'global'. By prioritising an acceptance of the concept's ambivalence and dynamic character in the context of continuing attempts to pin down a particular meaning or defined context in which references to governance occur, governance can fulfil the function of a highly adaptable concept for the complex study of evolving regulatory structures today. Governance, then, emerges less as a term, which depicts a territorially or historically identifiable form of political order, but as an expression of uneasiness in the face of the plurality of interpretations, mappings and definitions of its ongoing transformation, thereby constructing a space to further negotiate such pluralities

As the term governance cuts across different disciplines in illustrating the wide-ranging variations of its use and historical and theoretical embeddedness, the question of purpose of this interdisciplinary foray moves into the foreground. It becomes obvious that the concept shares essential elements with ideas such as, for example, justice, sovereignty, or order. Like these, governance expresses a problematic ambivalence, which results from the concept's two core dimensions. On the one hand, the concept can function to merely identify, describe and capture an existing form and content of order. In that sense, one speaks of the governance system found in organisations such as business corporations or the church or that, which marks a particular area of social activity. On the other hand, however, the concept has a fluid dimension, which can be programmatic in nature or bear critical and investigative character.

\footnotetext{
${ }^{36}$ Max Weber, The City

${ }^{37}$ Young, 1990; Frug, 1980

${ }^{38}$ Bakan/Blomley, 1992

${ }^{39}$ Krugman, 1998; for a discussion see David, 1999.

${ }^{40}$ See the contributions to Hall/Soskice, 2001, and Hancké, 2009.
} 
This tension can be expressed by the juxtaposition of two distinct intra-disciplinary approaches to and uses of the concept. In law, particularly in legal sociology as well as in many fields of both public and private law, references to governance point to the transformational character of existing institutional frameworks of order. For public lawyers, governance has been giving expression to a fundamental shift in the organisation and implementing of public service delivery as well as rule-making. ${ }^{41}$ Governance, in this context, carries the burden of being the comprehensive construction site for an encompassing reconsideration of the particularly 'public' nature of legislation, administration and adjudication. Meanwhile, in private law, governance appears to be an attractive concept to illustrate the larger, systematic dimensions of otherwise 'private' conduct. Governance studies in the contexts, for example, of contract and corporate law are thus concerned with the critical analysis of the otherwise unquestioned assumptions that lead to the classification of an activity as either private or public. ${ }^{42}$

\section{A. The EXAmple of Corporate Governance}

The association of an activity as well as of its regulation with either the public or the private sphere is a core trait of almost any reference to governance. At a minimum, such references incorporate an indication of the overarching direction of the regulatory thrust captured in the existing governance form. As an illustration, corporate governance as a field that held centre stage in company law research and policy making from the early 1990s until the latter half of the new millenium's first decade, is regularly conceived of as being concerned with the interests of those invested in the business enterprise. Corporate governance, then, is presented as a focus field for company law, which belongs to private law because its regulatory aspiration extends only to the private interests channelled through the corporation. ${ }^{43}$ The underlying governance mechanism is a contract or, rather, a nexus of contracts that holds together the different interests in the corporation. ${ }^{44}$ The contestation of this dominating thesis occurs without any interdisciplinary input, but internally to the theoretical construction of the concept of the business corporation. Positing that the entering and modifying of contractual relations occurs on the basis of assigned rights, critics of the dominating corporate governance model reject the idea of business regulation as a 'private' affair. ${ }^{45}$

\footnotetext{
${ }^{41}$ Aman Jr., 2007; Vincent-Jones, 2006

${ }^{42}$ See, eg, Deakin/Lane/Wilkinson, 1997, and Friedmann, 1957.

${ }^{43}$ Kraakman/Davies/Hansmann/Hertig/Hopt/Kanda/Rock, 2004

${ }^{44}$ Williamson, 1985, ch. 12

${ }^{45}$ Bratton, 1989
} 
The tension between these two approaches to capturing the nature of corporate governance is powerfully captured by assuming an interdisciplinary perspective: from the point of view of the already mentioned New Institutional Economics [NIE], corporate governance is above all a mechanism of private ordering, which is predominantly construed through informal institutions, including the arrangements among the different contractual partners in the corporation. These private arrangements are seen to be embedded in an ideally 'noninterventionist' framework of formal rules, including corporate law and securities regulation. The NIE's depiction of the co-existence of informal and formal institutions governing the corporation is echoed by the dominant interpretation of US American corporate law, which is described as being 'enabling' in nature. According to this view, corporate law couches and complements an otherwise unfettered realm of 'private', corporate self-regulation. The core of the models forthcoming from NIE as well as from corporate law in this regard is the distinct demarcation of the rule-making processes in and around the corporation. While the majority of arrangements created to run and to govern the corporation are allegedly private in nature and distinct from legal intervention, law extends only to the institutional and regulatory framework, in which the (private) ordering occurs. As a consequence of this model, the process and the substance of the internal organisation of the corporation is represented as the result of private, mostly individual choices. These stand in stark contrast, allegedly, to the political pressure exerted on the corporation 'from outside', through the state, the 'public' or societal interests, altogether demarcated from the shareholder/investor group as so-called 'stakeholders'.

\section{B. Governance CarRies the tension betWeen Affirmation ANd CRITIQUe}

This example must serve as a stand-in for what must necessarily be a more extensive illustration of how the concept of governance operates to demarcate different levels or spheres of societal activity. The field of corporate governance highlights the complex relations between differently conceived levels of action and control. This demarcation has significant consequences for the way in which governance is understood in this particular context. The demarcation of a private, allegedly informal, more or less non-legal, self-regulatory and nonpolitical sphere from a public, 'interventionist' legal framework underscores the way in which governance can serve as a quasi-neutral observation of boundaries. In the described example, corporate governance offers a description of a regulated area, which is based on a series of crucial assumptions and distinctions which in themselves are not exposed to further scrutiny.

As the above example illustrates the contestable nature of the concept's employment to describe the mode of regulation in a given area, we can easily defer the existence of other comparable instances, in which reference to governance obscure more than they serve to lay bare or clarify. Unsurprisingly, references to governance in different areas are regularly met by contesting allusions to the undisclosed political (and other) assumptions of the use of the concept or by an outcry of protest in view of the matter-of-fact employment of the concept to depict changes in political control, democratic accountability with insufficient capacity to challenge these processes from a critical perspective. ${ }^{46}$

\footnotetext{
${ }^{46}$ For a good illustration in the area of European law, see Möllers, 2006.
} 
As seen above, the use of the concept and the contestation of that use occurs without a necessary interdisciplinary element. The relative ambiguity and the already mentioned conceptual openness and lack of definitional clarity of the term subject governance to a host of critiques, which are internal to a given discipline. Meanwhile, it is this set of characteristics that we find recurring in different disciplinary uses of the concept and which points to the crosscutting nature of the concept. It is this dimension of governance that makes the term a crucial concept within contemporary social theory. Rather than merely being an idea, which we can be found in different disciplinary discourses, governance bridges a series of investigations and inquiries across different disciplinary boundaries. Governance, in other words, is essentially interdisciplinary in that it unfolds its ambivalent role - being potentially both affirmative and critical - only through the interplay of different disciplinary approaches to a regulatory area.

\section{GOVERNANCE AS INTERDISCIPLINARY CONCEPT}

It follows from this observation that there cannot be a meaningful use or critique of the concept, which remains confined to the analytical and theoretical framework of one given discipline. Instead, governance operates always already in contestation of boundaries between disciplines. As illustrated in the example of corporate governance, the tension between the legal and the economic modelling of the corporation is fully captured only through the use of the concept. In the very moment that we place side by side the distinct assumptions, which inform a particular field's approach to governance (and its respective contestations), the concept emerges as the crucial bridging element that inseparably ties these different approaches together to unfold into a necessarily pluralistic and interdisciplinary understanding of the concept. By unravelling the way in which governance is being theorised within different disciplines, the concept underlines the impossibility of merely sticking to the governance concept of one discipline over the other. Rather, any reference to governance now prompts the inclusion of competing disciplinary interpretations of the regulatory challenge from different disciplinary backgrounds into what might have started out as an analysis of the regulatory challenges arising from a particular field (for a particular discipline).

This cross-cutting dimension of governance echoes the nature of the regulatory landscapes which it is meant to address. As seen from the cursory overview of different emerging disciplinary usages of the concept, with which this chapter began, governance has been arising in response to perceived, dramatic changes in the analytical and conceptual toolkit with which a discipline has been theorizing the idea of 'order'. As was further seen, such changes have been associated with the transformation of state-based regulation within the nation-state as well as with the transformation of state-based sovereignty and rule-making in areas that by their very nature cut across different national boundaries. Oft-cited examples include environmental and security concerns, but also questions of political or social justice. ${ }^{47}$ What connects these

\footnotetext{
${ }^{47}$ Beck, 2009; Held, 1995
} 
allegedly distinct, 'global' regulatory challenges (environment, security, international human rights) to those that mostly remain associated with the nation state (welfare state reform, corporate law reform, tort law reform), is the way in which such areas are in fact different instantiations of encompassing regulatory arenas. Again, corporate governance and an indeed breathtaking international debate over the field's possible global 'convergence' in the last twenty years illustrates this connection. As corporations extended their operation and vast financial activities into the furthest corners of this world, national company law makers inevitably saw themselves making regulatory choices on what had become a global market for corporate regulation. ${ }^{48}$ The example of security regulation following the terrorist attacks from September 2001 is another telling illustration of the close connections between different national approaches to the problem, illustrated not to the least by the un-normally detailed regulatory implementation plan laid out in UN Security Council Resolution 1373 of 28 September $2001 .^{49}$

\section{Prospects of Governance}

Concluding this brief investigation into the interdisciplinary uses of and approaches to governance, this last section will touch on two areas, which have putting forward crucial regulatory challenges and will be crucial to further shape the concept of governance and its prospects - the market and religion. Not only throughout the last decades of the twentieth century, but long before have markets been at the centre of social theorists' conceptualisations of order. ${ }^{50}$ Hardly another term so well captures the symbolism of an organizing metaphor. Meanwhile, religion merits our attention as an illustration of highly complex processes of societal differentation. Religion as an approach to governance thus promises to provide an exceptionally broad platform for the reconstruction of the tension between secularization and counter-secularisation, playing out between the poles of the individual and the collective, the public and the private, or universalism and particularity.

\section{A. Market GovernanCe}

Harkening back to Adam Smith's depiction of economic activity, the market has seemingly forever held a central place in the economic, sociological, legal and cultural imagination. The idea of market governance, which has been accompanying the theoretisation of markets for the longest time well expresses the concept's ambivalence and double-meaning. Governing markets and governing of markets represent fundamentally opposed, yet complementary and inseparable dimensions of markets. Not being an abstract entity or empty space, markets are a term formidably laden with assumptions, the full dimension of which remain more often than

\footnotetext{
${ }^{48}$ O'Hara/Ribstein, 2009

${ }^{49}$ http://daccess-ods.un.org/TMP/1073386.66915894.html

${ }^{50}$ Smith, 1991; Polanyi, 2001; Fligstein, 1996
} 
not undisclosed and unscrutinised. For the purpose of introducing the idea of market governance in this chapter and with view to the still entirely uncertain prospects of market governance in the future, it is mandatory to- at least briefly - touch on a number of concepts of market governance. Acknowledging the critical degree of selectivity, such reconstruction is here tied to the continuing attempts to develop a legal concept of the market and shall thus begin with the American economist's Robert Hale's critique of free-market ideology. In his writings ${ }^{51}$, Hale launched a poignant rejection of the notion of quasi-natural, self-regulating markets populated by natural persons operating on discretionary terms alone. In contrast to those until the present day highly influential views - Hale posited that markets are indeed highly regulated arenas. Not only are the activities occurring on the market subject to far-reaching regulation, but already the entering of a person (or a corporation, for that matter) onto the market must be seen through the lens of rights, which grant the person (or, corporation) particular freedoms, while conferring other duties and obligations. In stark opposition to depictions of market governance as a largely unfettered realm of private ordering, Hale underscored the crucial role of political regulation, which reveals itself in every aspect of market activity.

Karl Polanyi's famous analysis of the disembeddedness of markets, which he unfolded in $1944^{52}$, constituted an important mile-stone in the social theorizing of markets as governance arenas. By depicting the hegemonic thrust of commodification extending into areas such as land, labour and money, Polanyi offered a sobering analysis of the pressure for any attempt of regulation to strike a meaningful balance between what he referred to as the 'double movement' between liberal emancipation on the one hand and taming of destructive commodification on the other.

After a long phase of breathtaking economic prosperity in the West following the conclusion of World War II, there seemed to be little incentives to heed the warnings of the Hungarian economist and social theorist to counter the disjuncture of society and markets. The dramatic collapse of financial markets between 2007 and 2009 appears to offer a serious opportunity for a new and sustained engagement with Polanyi's ideas. At the same time, the overwhelming references to the lack of regulation leading up to the crisis suggest a disconcerting naivety with regard to the way in which regulation in fact did facilitate the expansion of global finance. ${ }^{53}$

\footnotetext{
${ }^{51}$ See Hale, 1923, and Hale, 1943.

${ }^{52}$ Polanyi, 1944

${ }^{53}$ Dore, 2008; Mitchell, 2010
} 


\section{B. SeCULAR GOVERNANCE AND THE CHALlenge OF RELIGION}

Finally, religion. Not only through the alarming shock of the 9/11 attacks in the United States did the issue of religious challenges to secular governments assume a front place in the global public consciousness. Long before had the tensions between religion-based claims for selfdetermination, authority and autonomy on the one hand and secular appeals to universalistic equalisation become strikingly apparent within societies around the world. The so-called 'end of history', proclaimed in the aftermath of the fall of the Berlin wall and the erosion of the Soviet bloc, occurred together with the claim that henceforth regional, ethnic and religious conflicts would become the central form of military confrontation. ${ }^{54}$ Echoing such depictions, social theorists long laid out the challenges of a 'shrinking world' a result of which would be the inevitable confrontation of different world views and models of political (cultural, economic and legal) authority.

Against this background, regional conflicts, that would only inadequately have been depicted as civil war instances of a (merely) political nature,showed a deeply religious substance and attracted heightened international attention. In the attempt to cut through and to eventually neutralise what at the core had been a religious-political conflict, a powerfully, militarily-backed rhetoric all too readily subsumed distinctly evolved local conflicts to a problematically 'universalising' logic, resulting in the troubling occurrence of 'humanitarian interventions', as was strikingly illustrated by the non-UN sanctioned military action in Kosovo. ${ }^{55}$

Meanwhile, Western democracies have been experiencing an impressive surge in religionbased conflicts, extending from, inter alia, conflicts over religious communities to build places of worship to the rights to display signs of religious belief in public and to the claim to withhold medical care for religious reasons. ${ }^{56}$

Much of the development of human rights conflicts centered around matters of religious belief suggests that religion is and will indeed be the governance challenge of the future. ${ }^{57}$ For the present attempts to further demarcate and thus operationalise the concept of governance to meet the regulatory challenges as indicated until now, religion appears to offer yet another host of challenges. The comprehensive nature of religious systematic order, transcending traditional public-private splits, poses formidable tasks not only from the perspective of different regulatory attempts. Religion itself constitutes an inherently complex realm the adequate interpretation of which (and concurring observance, or compliance) by its members is

\footnotetext{
${ }^{54}$ Fukuyama, 1992

${ }^{55}$ Orford, 2003

${ }^{56}$ Ladeur/Augsberg, 2007

${ }^{57}$ An-Naim, 2010; see also Manow, 2008
} 
the defining quality of a religious system..$^{58}$ Tracing secular-religious conflicts back to Antiquity's Antigone through the European religious wars of the $17^{\text {th }}$ and $18^{\text {th }}$ centuries to the disconcertingly neglected complexity of religious differences in the areas of international military and economic intervention today, the result is open. While the complexity of religious systems has forever been beguiling political and legal thinkers ${ }^{59}$, the pressing nature with which religious-secular conflicts have been coming to the foreground underscores the need to work towards a theoretically and conceptually open and sensitive understanding of governance in this area.

${ }^{58}$ Atran, 2002

${ }^{59}$ Schmitt, 1984 
Selected Bibliography

Aman Jr., A., Law, Markets and Democracy: A Role for Law in the Neo-Liberal State, (2007) 51 New York Law School Review 802

An-Naim, A. A., The Compatibility Dialectic: Mediating the Legitimate Coexistence of Islamic Law and State Law, (2010) 73 Modern Law Review 1-29

Atran, S. (2002). In Gods We Trust. The Evolutionary Landscape of Religion. New York City: Oxford University Press, 2002.

Bakan, J. C. \& Blomley, N. K., Spacing Out: Towards a Critical Geography of Law, (1992) 30 Osgoode Hall Law Journal 661-690

Beck, U. (2009). World at Risk [orig. German "Weltrisikogesellschaft" (Frankfurt: Suhrkamp); Ciaran Cronin, transl.]. Cambridge, UK \& Malden, MA (U.S.A.): polity, 2009.

Braithwaite, J. (2008). Regulatory Capitalism. How it Works, Ideas for Making it Work Better. Cheltenham, UK: Edward Elgar, 2008.

Bratton, W. W., The 'Nexus of Contracts' Corporation: A Critical Appraisal, (1989) 74 Cornell Law Review 407-465

Chakrabarty, D. (2007). Provincializing Europe. Postcolonial Thought and Historical Difference, 2nd ed. [orig. 2000]. Princeton, NJ: Princeton University Press, 2007.

Conrad, S. \& Osterhammel, J. (eds), Das Kaiserreich transnational. Deutschland in der Welt 1871 - 1914 2004)

David, P. A., Krugman's Economic Geography of Development: NEGs, POGs, and Naked Models in Space, (1999) 22 International Regional Science Review 162-172

Deakin, S., Lane, C. \& Wilkinson, F. (1997). Contract Law, Trust Relations, and Incentives for Cooperation: A Comparative Study. In S. Deakin \& J. Michie (eds), Contracts, Co-operation, and Competition. Studies in Economics, Management and Law. Oxford/New York: Oxford University Press, 105-139

Dezalay, Y. \& Garth, B. (1996). Dealing in Virtue: International Commercial Arbitration and the Construction of a Transnational Legal Order. Chicago: Chicago University Press, 1996.

Dore, R., Financialization of the Global Economy, (2008) 17 Industrial and Corporate Change 1097-1112

Ehrlich, E. (1962). Fundamental Principles of the Sociology of Law (orig. published in German as Grundlegung der Soziologie des Rechts, 1913). New York: Russell \& Russell, 1962.

Fligstein, N., Markets as Politics: A Political-Cultural Approach to Market Institutions, (1996) 61 American Sociological Review 656-673

Foucault, M. \& Miskowiec, J., Of Other Spaces, (1986) 16 Diacritics 22-27

Friedmann, W. G., Corporate Power, Government by Private Groups, and the Law, (1957) 57 Columbia Law Review 155-186

Frug, G., The City as a Legal Concept, (1980) 93 Harvard Law Review 1057-1154

Fukuyama, F. (1992). The end of history and the last man. New York: Macmillan, 1992.

Garth, B., Introduction: Taking New Legal Realism to Transnational Issues and Institutions, (2006) 31 Law \& Soc. Inquiry 939-945

Hale, R. L., Coercion and Distribution in a Supposedly Non-Coercive State, (1923) 38 Political Science Quarterly 470-494

Hale, R. L., Bargaining, Duress and Economic Liberty, (1943) 43 Columbia Law Review 603-628 
Hall, P. A. \& Soskice, D. (eds), Varieties of Capitalism. The Institutional Foundations of Comparative Advantage (Oxford University Press, 2001)

Hancké, B. (ed) Debating Varieties of Capitalism. A Reader (Oxford University Press, 2009)

Harvey, D., The Sociological and Geographical Imaginations, (2005) International Journal of Politics, Culture and Society 211-256

Held, D. (1995). Democracy and the Global Order. Cambridge: Polity Press, 1995.

Jessup, P. C. (1956). Transnational Law. New Haven: Yale University Press, 1956.

Kraakman, R., Davies, P. L., Hansmann, H., Hertig, G., Hopt, K. J., Kanda, H. \& Rock, E. B. (2004). The Anatomy of Corporate Law. A Comparative and Functional Approach, 2nd ed. 2009. Oxford/New York: Oxford University Press, 2004.

Krugman, P., What's new about the new economic geography?, (1998) 14 Oxford Review of Economics \& Politics 7-17

Ladeur, K.-H. \& Augsberg, I., The Myth of the Neutral State: The relationship between state and religion in the face of new challenges, (2007) 8 German L.J. 143-152

Latour, B. (1993). We have never been modern (Catherine Porter transl.). Cambridge, MA: Harvard University Press, 1993.

Latour, B. (2005). From Realpolitik to Dingpolitik, or How to make things public. In B. Latour \& P. Weibel (eds), Making Things Public. Atmospheres of Democracy. Cambridge, MA: ZKM Art and Media Centre, Karlsruhe/MIT Press, 14-41

Levi-Faur, D., The Global Diffusion of Regulatory Capitalism, (2005) 598 The Annals of The American Academy of Political and Social Science 12-29

Manow, P. (2008). Religion und Wohlfahrtsstaat. Die konfessionellen Grundlagen europäischer Wohlfahrtsstaatsregime. Frankfurt \& New York: Campus, 2008.

Mitchell, L. E. (2010). Financialism - A (Very) Brief History. In P. Zumbansen \& C. A. Williams (eds), The Embedded Firm: Corporate Governance, Labour and Financial Capitalism. Cambridge, UK: Cambridge University Press, forthcoming

Möllers, C., European Governance: Meaning and Value of a Concept, (2006) 43 Common Market Law Review 313-336

Moore, S. F., Law and Social Change: the semi-autonomous field as an appropriate subject of study, (1973) 7 Law \& Society Review 719-746

O'Hara, E. A. \& Ribstein, L. E. (2009). The Law Market. Oxford, UK: Oxford University Press, 2009.

Orford, A., Muscular Humanitarianism: Reading the Narratives of the New Interventionism, (2003) 10 Eur. J. Int'l L. 679-711

Polanyi, K. (1944). The Great Transformation. The Political and Economic Origins of our Time. Boston: Beacon Press, 1944.

Polanyi, K. (2001). The Economy as an Instituted Process [1957]. In M. Granovetter \& R. Swedberg (eds), The Sociology of Economic Life. Westview, 31-50

Pottage, A., Instituting Property, (1998) 18 Oxford Journal of Legal Studies 331-344

Riles, A., A New Agenda for the Cultural Study of Law: Taking on the Technicalities, (2005) 53 Buffalo Law Review 973 
Rittich, K., Functionalism and Formalism: Their latest Incarnations in Contemporary Development and Governance Debates, (2005) 55 University of Toronto Law Journal 853-868

Santos, A. (2006). The World Bank's Uses of the 'Rule of Law' Promise in Economic Development. In D. Trubek \& A. Santos (eds), The New Law and Economic Development. A Critical Appraisal. Cambridge: Cambridge University Press, 253-300

Sassen, S., The City: Its Return as Lens for Social Theory. Keynote presentation at the International Conference for Integrating Urban Knowledge \& Practice, Gothenburg, Sweden, May 29 to June 5, 2005, (2005) http://www.urbanlife2005.com/proceedings/keynotes/Saskia Sassen.pdf

Sassen, S. (2006). Territory - Authority - Rights. From Medieval to Global Assemblages. Princeton, NJ/Oxford, UK: Princeton University Press, 2006.

Schmitt, C. (1984). Römischer Katholizismus und politische Form (1925). Stuttgart: Klett-Cotta, 1984.

Scott, C. (2004). Regulation in the Age of Governance: The Rise of the Post Regulatory State. In J. Jordana \& D. Levi-Faur (eds), The Politics of Regulation: Institutions and Regulatory Reforms for the Age of Governance. Cheltenham: Edward Elgar, 145-174

Scott, C. M., 'Transnational Law' as Proto-Concept: Three Conceptions, (2009) 10 German Law Journal 859-876

Smith, A. (1991). Wealth of Nations [1776]. Amherst, NY: Prometheus Books, 1991.

Vincent-Jones, P. (2006). The New Public Contracting. Regulation, Responsiveness, Relationality. Oxford/New York: Oxford University Press, 2006.

Vismann, C. (2000). Akten. Medientechnik und Recht. Frankfurt: Fischer, 2000.

Vismann, C., Jurisprudence: A Transfer Science, (2000) 10 Law and Critique 279-286

Weiss, T. G., Governance, good governance and global governance: conceptual and actual challenges, (2000) 21 Third World Quarterly 795-814

Werner, M. \& Zimmermann, B., Beyond comparison: Histoire croisée and the challenge of reflexivity, (2006) 45 History and Theory 30-50

Williamson, O. (1985). The Economic Institutions of Capitalism. New York/London: Free Press/MacMillan, 1985.

Wilson, R. A. (2006). Tyrannosaurus Lex: The Anthropology of Human Rights and Transnational Law. In M. Goodale \& S. E. Merry (eds), The Practice of Human Rights: Tracking Law Between the Global and the Local. Cambridge, UK: Cambridge University Press, 342-369

Young, I. M. (1990). Justice and the Politics of Difference. Princeton, NJ: Princeton University Press, 1990.

Zumbansen, P. (2006). Transnational Law. In J. Smits (ed) Encyclopedia of Comparative Law. Edward Elgar, 738-754

Zumbansen, P., Transnational Legal Pluralism, (2010) 1 Transnational Legal Theory 141-189 (http://ssrn.com/abstract=1542907) 